\title{
Pelvic mass in von Recklinghausen's neurofibromatosis: diagnostic issues: a case report Nicolas Kluger ${ }^{1}$, Hélène Perrochia ${ }^{2}$ and Bernard Guillot*1
}

\author{
Address: ${ }^{1}$ Université Montpellier I, Service de Dermatologie, Hôpital Saint-Eloi, CHU de Montpellier, 80, avenue Augustin Fliche, FR-34295 \\ Montpellier cedex 5, France and '2Université Montpellier I, Service d'Anatomie et Cytologie Pathologiques, Hôpital Lapeyronie, CHU de \\ Montpellier, France \\ Email: Nicolas Kluger - nicolaskluger@yahoo.fr; Hélène Perrochia - h-perrochia@chu-montpellier.fr; Bernard Guillot* - b-guillot@chu- \\ montpellier.fr \\ * Corresponding author
}

Published: 12 November 2009

Cases Journal 2009, 2:191 doi:10.1186/1757-1626-2-191

This article is available from: http://www.casesjournal.com/content/2/I/I9I

(C) 2009 Kluger et al; licensee BioMed Central Ltd.

This is an Open Access article distributed under the terms of the Creative Commons Attribution License (http://creativecommons.org/licenses/by/2.0), which permits unrestricted use, distribution, and reproduction in any medium, provided the original work is properly cited.

\begin{abstract}
Background: Leiomyomas are benign smooth muscle cell tumours. They are the most common uterine neoplasms, although they may also occur elsewhere, such as in the gastrointestinal and urinary tracts. Leiomyomas are uncommon in von Recklinghausen's neurofibromatosis (NFI). However, the literature suggests that the association of NFI and leiomyomas or leiomyosarcoma is not entirely coincidental.
\end{abstract}

Case Report: We report here the unusual case of a 47-year-old woman with NFI who presented menorrhagias and a hard, tender pelvic mass composed of uterine leiomyomas. Positron emission tomography/computed tomography disclosed an area of increased 18-fluorodeoxyglucose (FDG) uptake in the upper right part of the mass that raised the suspicion of malignancy. Magnetic resonance imaging revealed numerous intramural leiomyomas ranging from 1 to $6 \mathrm{~cm}$, including a 6-cm submucosal leiomyoma that had abundant cellularity, matching FDG uptake. Abdominal hysterectomy was performed and microscopic examination confirmed the diagnosis of multiple benign smooth muscle tumours (uterine leiomyomatosis).

Conclusion: Our case illustrates several diagnostic issues that arose while exploring this pelvic mass. Moreover, the association of uterine leiomyoma and NFI may not be fortuitous.

\section{Introduction}

Leiomyomas are benign smooth muscle cell tumours. They are the most common gynaecologic and uterine neoplasms, although they may also occur in other organs [1]. These tumours are an uncommon finding in von Recklinghausen's neurofibromatosis (NF1). The literature suggests, however, that the association of NF1 and leiomyomas or leiomyosarcoma may not be merely coincidental, as documented by various case reports $[2,3]$. In the context of NF1, leiomyomas mostly affect the gas- trointestinal tract with multiple lesions, showing predominance in the proximal small bowel. We report here a patient with NF1 who presented with an abdominal mass that was found to be uterine leiomyomatosis. We particularly emphasise several diagnostic issues that arose while exploring this patient and discuss the potential association of the two conditions. 


\section{Case Presentation}

A 47-year-old woman was followed for sporadic NF1 diagnosed by the association of numerous café-au-lait spots, cutaneous neurofibromas (NFBs) of the limbs and trunk, nodular NFBs of the scalp, and a plexiform NFB of the ankle. Her medical history was notable for a thoracic paraspinal NFB extending into the neural foramina of T12-L1, which had been resected neurosurgically in 2005, and numerous cutaneous NFBs treated by CO2 laser sessions on a regular basis. During follow-up, a 10-cm, hard, tender pelvic mass was discovered that had been absent at the prior examination 12 months earlier. She acknowledged having experienced menorrhagias and pelvic pain and pressure for several weeks. Laboratory testing revealed decreased ferritin ( $3 \mathrm{ng} / \mathrm{ml}, \mathrm{N}>11$ ) without anaemia and a mild inflammatory syndrome with a slightly elevated erythrocyte sedimentation rate at $30 \mathrm{~mm}$, elevated fibrinogen of $5.5 \mathrm{mg} / \mathrm{l}(\mathrm{N}<4 \mathrm{mg} / \mathrm{l})$, and C-reactive protein within the normal range. Transabdominal ultrasound imaging displayed numerous leiomyomas with a normal endometrium. Positron emission tomography/computed tomography (PET/CT) disclosed an area of increased 18fluorodeoxyglucose (FDG) uptake in the upper right part of the pelvic mass. Magnetic resonance imaging (MRI) was then performed to evaluate the diagnosis of uterine leiomyomatosis, to map the lesions, and to rule out the diagnosis of NFB or malignant lesion-like sarcoma. MRI confirmed numerous intramural leiomyomas ranging in size from 1 to $6 \mathrm{~cm}$. A $6-\mathrm{cm}$ submucosal leiomyoma displayed abundant cellularity, matching the FDG uptake on PET/CT. The endometrium and ovaries were normal. The patient subsequently underwent abdominal hysterectomy without salpingo-oophorectomy to rule out a malignant lesion. The specimen consisted of a uterus with attached cervix. The uterus measured $14 \times 12 \times 10 \mathrm{~cm}$ and the cervix measured $4 \times 3 \mathrm{~cm}$. The myometrium contained multiple nodules consistent with intramural, submucosal and subserosal leiomyomas. The endometrium was smooth without anomaly. Microscopic examination of the myometrium revealed long fascicles of spindle cells without nuclear atypia and eosinophilic cytoplasm, few mitotic figures $<1 / 10$ (at $\times 400)$ and no tumour necrosis. The endometrium and the cervix were normal. The aspect was in favour of multiple benign smooth muscle tumours (uterine leiomyomatosis). No leiomyosarcoma or neurofibroma was diagnosed.

\section{Discussion}

Leiomyomas, which are benign smooth muscle cell tumours, are the most common uterine neoplasms. Approximately 20-30\% of women over 35 years with uterine leiomyomas have clinical manifestations (menorrhagia, pelvic pain, pressure) [1]. Extrauterine leiomyomas are much less frequent and may be located at any anatomic site including the genitourinary tract (vulva, ovaries, urethra, and urinary bladder) and the gastrointestinal tract [1].

We report here a case of uterine leiomyomatosis in a 47year-old patient with NF1 that raised some diagnostic issues. The lesions were asymptomatic until the patient presented within a year of her last examination with a highly suspect, tender abdominal and pelvic mass. Moreover, one of the lesions displayed focal FDG uptake, suggesting a potential neoplastic lesion. However, MRI confirmed that the lesion was a leiomyoma with abundant cellularity. This situation is uncommon but not rare in pre- and post-menopausal women. Abundant cellularity and hormonal dependency without malignant transformation are responsible for such uptake $[4,5]$. Another question raised by the PET/CT scan results was whether or not these lesions were NFBs or even a malignant transformation of a uterine NFB. Unfortunately, the PET/CT scans demonstrated varying degrees of FDG uptake in benign NFBs [6]. Therefore, PET/CT may not be a useful discriminating exam in this peculiar gynaecologic situation. Of note, our patient did not have any indication of a familial history of cutaneous and uterine leiomyomatosis [7].

At first glance, the association of uterine leiomyoma and NF1 may seem coincidental, as the first condition is frequent in the general population. However, there are several reports suggesting a true link between leiomyoma and NF1. The NF1 gene is a tumour suppressor gene located on chromosome 17 that encodes neurofibromin, a widely expressed negative regulator of intracellular RAS signalling in various tissues. Patients with NF1 are prone to develop various tumours. Case reports of gastrointestinal leiomyomas in patients with NF1 have been described on a regular basis in the literature since the fifties $[2,8,9]$. Patients are usually diagnosed with multiple tumours of the small intestine in a context of anaemia and gastrointestinal bleeding $[2,10]$. In addition, anecdotal cases of leiomyma and leiomyosarcoma of the urinary tract have been reported $[11,12]$. To the best of our knowledge, only Mellor Pita et al reported a case of a 40 -year-old woman with NF1 and an abdominal mass that revealed both uterine and gastric leiomyomas [13]. Moreover, Wei et al reported the case of a 39-year-old woman with a plexiform NFB of the uterus associated with adenomyosis and uterine leiomyoma [14]. The female genital system is rarely affected during NF1 [14]. NFBs are most commonly located on the vulva, but other locations such as the clitoris, vagina, myometrium and ovary have occasionally been reported. There are also very few cases of uterine cervical NFBS [14]. Differential diagnoses of uterine NFB include schwannoma, neuroma, leiomyoma and myxoma [14]. 


\section{Conclusion}

We here report a new case of uterine leiomyomatosis during NF1. This condition may be under-recognised because uterine leiomyomas are frequent in the general population. Physicians should keep in mind that female patients with NF1 presenting nonspecific symptoms such as menorrhagias, pelvic pain, discomfort and pressure should be examined for pelvic conditions including neurofibromas and leiomyomas $[14,15]$. In our opinion, the true incidence of uterine leiomyoma associated with NF1 deserves to be explored in a larger series of female patients with NF1, given the previously reported cases of NF1-associated leiomyoma of the gastrointestinal and urinary tracts.

\section{Consent}

Written informed consent was obtained from the patient for publication of this case report.

A copy of the written consent is available for review by the Editor-in-Chief of this journal.

\section{Competing interests}

The authors declare that they have no competing interests.

\section{Authors' contributions}

NK and BG made major contributions to conception and design, acquisition of data, analysis and interpretation of data and drafting the manuscript. HP performed the pathological examination of the leiomyomas and was involved in drafting the manuscript and critically revising it for important intellectual content. All authors read and approved the final manuscript.

\section{References}

I. Fasih N, Prasad Shanbhogue AK, Macdonald DB, Fraser-Hill MA, Papadatos D, Kielar AZ, Doherty GP, Walsh C, Mclnnes M, Atri M: Leiomyomas beyond the uterus: unusual locations, rare manifestations. Radiographics 2008, 28: 1931-48.

2. Cox JG, Royston CM, Sutton DR: Multiple smooth muscle tumors in neurofibromatosis presenting with chronic gastrointestinal bleeding. Postgrad Med J 1988, 64:|49-I5I.

3. Schmid RA, Schöb OM, Klotz HP, Vogt P, Weder W: VATS resection of an oesophageal leiomyoma in a patient with neurofibromatosis Recklinghausen. Eur J Cardiothorac Surg 1997, I 2:659-62.

4. Nishizawa S, Inubushi M, Kido A, Miyagawa M, Inoue T, Shinohara K, Kajihara M: Incidence and characteristics of uterine leiomyomas with FDG uptake. Ann Nucl Med 2008, 22:803-10.

5. Khademi S, Westphalen AC, Webb EM, Joe BN, Badiee S, Hawkins RA, Coakley FV: Frequency and etiology of solitary hot spots in the pelvis at whole-body positron emission tomographyl computed tomography imaging. Clin Imaging 2009, 33:44-8.

6. Son JM, Ahn MI, Cho KD, Yoo J, Park YH: Varying degrees of FDG uptake in multiple benign neurofibromas on PET/CT. $\mathrm{Br} J$ Radiol 2007, 80:e222-6.

7. Marque M, Avril MF, Bressac de Paillerets B, Guillot B, Richard S, Bessis D: Familial cutaneous and uterine leiomyomatosis. Ann Dermatol Venereol 2008, 135:612-6.

8. Ishizaki $Y$, Tada $Y$, Ishida $T$, Bandai $Y$, Idezuki $Y$, Hitoshi N, Mitio I: Leiomyosarcoma of the small intestine associated with von Recklinghausen's disease: report of a case. Surgery 1992, I I I:706-7|0.
9. River L, Silverstein J, Tope JW: Benign neoplasm of the small intestine: a clinical comprehensive review with reports of 20 new cases. Int Surg 1956, 102:1-38.

10. Chu MH, Lee HC, Shen EY, Wang NL, Yeung CY, Chen BF, Shih SL: Gastro-intestinal bleeding caused by leiomyoma of the small intestine in a child with neurofibromatosis. Eur J Pediatr 1999, I 58:460-2.

II. Däuth TL, Conradie M, Chetty R: Leiomyoma of the bladder in a patient with von Recklinghausen's neurofibromatosis. J Clin Pathol 2003, 56:7II-2.

12. Poleksic S: Leiomyosarcoma of urinary bladder in von Recklinghausen's neurofibromatosis. Urology 1977, 10:34I-2.

13. Mellor Pita S, Yebra Bango M, González Hernando C, Ramón y Cajal $\mathrm{S}$ : Von Recklinghausen's disease and abdominal mass. Rev Clin Esp 1999, 199:759-60.

14. Wei EX, Albores-Saavedra J, Fowler MR: Plexiform neurofibroma of the uterine cervix: a case report and review of the literature. Arch Pathol Lab Med 2005, I 29:783-6.

15. McLucas B: Diagnosis, imaging and anatomical classification of uterine fibroids. Best Pract Res Clin Obstet Gynaecol 2008, 22:627-42.
Publish with BioMed Central and every scientist can read your work free of charge

"BioMed Central will be the most significant development for disseminating the results of biomedical research in our lifetime. " Sir Paul Nurse, Cancer Research UK

Your research papers will be:

- available free of charge to the entire biomedical community

- peer reviewed and published immediately upon acceptance

- cited in PubMed and archived on PubMed Central

- yours - you keep the copyright

Submit your manuscript here:

http://www.biomedcentral.com/info/publishing_adv.asp
BioMedcentral 